\title{
Thermal Treatment Influence on the Change of Alloy EN AW-6082 Mechanical Properties
}

Pavel Solfronk, Jiri Sobotka, Michaela Kolnerova, David Korecek

Faculty of Mechanical Engineering, Technical University of Liberec. Studentská 1402/2, 46117 Liberec

Czech Republic. E-mail: pavel.solfronk@tul.cz,jiri.sobotka@tul.cz,michaela.kolnerova@tul.cz, david.korecek@tul.cz

Thermal treatment of the aluminum alloys significantly affects their final mechanical properties. However, the process of such thermal treatment is influenced by many variables and the correct choice of these technological parameters is a prerequisite for achieving their required properties in the manufactured part. This paper evaluates the effect of thermal treatment conditions on the time course of hardness for EN AW-6082 alloy during artificial aging. For the experiment, the solution annealing temperature of $520^{\circ} \mathrm{C}$ was chosen in combination with three different holding times at this temperature and then also 3 different initial temperature of the material before cooling in water. The effect of the thermal treatment parameters was subsequently monitored by the Brinell hardness time course at 3 selected artificial aging temperatures.

Keywords: Alluminium Alloy EN AW-6082, Thermal Treatment, Brinell Hardness, Hot Forging, Solution Annealing

\section{Acknowledgement}

This publication was written at the Technical University of Liberec (TUL) as part of the Student Grant Contest "SGS 21122" with the support of the Specific University Research Grant, as provided by the Ministry of Education, Youth and Sports of the Czech Republic in the year 2017.

\section{References}

[1] ROUČKA, J. (2004) Metalurgie neželezných slitin, pp. 109-113. Akademické nakladatelství CERM, Brno.

[2] MICHNA, Š. a kol. (2005). Encyklopedie hliníku, pp. 379-409. Adin, s.r.o., Prešov.

[3] BIROL, Y., GOKCIL, E., ALI GUVENC, M., AKDI, S. (2016). Processing of high strength EN AW 6082 forgings without a solution heat treatment. In: Materials Science and Engineering: A, Vol. 674, pp. 25-32. Elsevier. Turkey.

[4] KOVAlČÍK, T., STOUlil, J., SLÁMA, P., VOJTĚCH, D. (2015). The Influence of Heat Treatment on Mechanical and Corrosion Properties of Wrought Aluminium Alloys 2024 and 6064. In: Manufacturing Technology, Vol. 15, No.1, pp. 54-61. UJEP. Czech Republic

[5] MARTINOVSKÝ, M., MÁDL, J. (2015). Effect of Different Modifiers and Heat Treatment on Structure, Hardness and Microhardness of AlSi7Mg0.3 Alloy. In: Manufacturing Technology, Vol. 15, No.4, pp. 604-610. UJEP. Czech Republic

[6] MRÓWKA-NOWOTNIK, G., SIENIAWSKI, J. (2005) Influence of heat treatment on the microstructure and mechanical properties of 6005 and 6082 aluminium alloys. In: Journal of Materials Processing Technology, Vol. 162-163, pp. 367-372. Elsevier. Poland. 